\title{
Insights into Consumer Preference of Foreign Brand Names: Reality or Myth?
}

\author{
Elif A. Ergin ${ }^{1}$, Handan O. Akbay ${ }^{1} \&$ Bulent Ozsacmaci ${ }^{2}$ \\ ${ }^{1}$ Department of Management, Çankaya University, Ankara, Turkey \\ ${ }^{2}$ Department of Foreign Trade, Çankaya University, Ankara, Turkey \\ Correspondence: Elif A.Ergin, Department of Management, Çankaya Üniversitesi Merkez Kampüs Yukariyurtçu \\ Mahallesi Mimar Sinan Caddesi No. 4 06790, Etimesgut, Ankara, Turkey. Tel: 9-0312-233-1230. E-mail: \\ elifrutgers@yahoo.com
}

Received: June 4, 2014 Accepted: June 20, 2014 Online Published: July 28, 2014

doi:10.5539/ijms.v6n4p157 URL: http://dx.doi.org/10.5539/ijms.v6n4p157

\begin{abstract}
This study builds from LeClerc et al.'s $(1989,1994)$ work on foreign branding effects, but it does so in the context of a developing East European country; as in the case of Turkey. The purpose of this exploratory research is to examine consumers' attitudes towards products with foreign brand names and also to assess the impact of foreign brand names on the purchasing decision making. In the data collection phase of the study an in-depth interviews were conducted with 23 participants in the city of Ankara, Turkey. The results show that products with foreign brand names elicit more positive consumer attitude than products with national brands. Overall, the findings suggest that consumers prefer to purchase products with foreign brand names for a variety of reasons which including quality, reliability, functionality and prestige. The results have important implications for domestic and foreign manufacturers with regards to the consumer-side effects of their decisions on branding strategies and on their competitive foreign branding decisions.
\end{abstract}

Keywords: brand management, consumer behavior, foreign branding, international marketing, purchasing decision

\section{Literature Review}

\subsection{Brand Name Concept}

Determining the value and importance of brand name for new product success has long been a discussion of both academics and managers. In today's market, even highly diversified products can easily be imitated, it is nearly impossible to perfectly position the new products. Companies do their best to implement various branding strategies in order to reduce the effect of this problem and to be preferred by the consumers and gain strategic advantage over their competitors. Brand name selection gets even more complex and more critical in view of a global marketplace, where brands become a key strategic resource for global expansion and competition (Soto, Mobarec \& Friedmann, 2009).

Brand names are key indicators of the products that have become an imperative asset that influences consumer brand perceptions in today's highly competitive environment (Ailawadi \& Keller, 2004). A brand can be basically delineated as a name, term, symbol, sign, design or any combination of them, intended to identify the goods and services of one seller or group sellers to differentiate them from those competitors (Kotler, 1994). Brand names simplify consumer choices by helping them to recognize products more easily (Friedman, 1985). Well-chosen brand names contribute to the strength of the product. Moreover, brand names that are associated with positive attributes score higher on overall liking (Kohli, Harich, \& Leuthesser, 2005).

A name can make substantial contributions to a brand's equity (Aaker, 1991), which is a key element to branding strategies and brand management. Brand equity concept is defined as an "added value" that brand knowledge has on consumers' responses to the marketing of a brand (Aaker, 1991; Farquar, 1989; Keller, 1993). Keller (1993) classifies two distinct components of brand knowledge, which are also the two bases of brand equity: brand awareness and brand image. Brand awareness is the consumer's ability to recognize and/or recall a brand (Aaker, 1991; Keller, 1993). Brand awareness basically composes of two dimensions; one is brand recognition that the ability of consumers to confirm previous exposure to the brand and the other one is brand recall, the ability of 
consumers to retrieve the brand when given the product category as a cue (Keller, 1993). Brand image is the brand's current set of associations (in the consumer's mind), or how the brand is seen by consumers (Aaker \& Joachimsthaler, 2000; Aaker, 1996; Park, Jaworski, \& MacInnis, 1986; Raggio \& Leone, 2005). A brand association is "anything that connects the customer to the brand". It can include user imagery, product attributes, use situations, organizational associations, brand personality, and symbols (Aaker \& Joachimsthaler, 2000). There are three types of brand associations: attributes, benefits, and attitudes (Keller, 1993). It is important to note that brand associations, collectively, make up the meaning of the brand in the minds of consumers (Aaker \& Joachimsthaler, 2000; Aaker, 1991; Keller, 1993, 1998).

\subsection{Foreign Branding}

Finding, or creating a brand name may involve pure invention, looking for appropriate names in native or foreign linguistic systems (i.e., languages), or a combination of these alternatives (Soto, Mobarec, \& Friedmann, 2009). This is a detailed research requiring decision for firms to choose a convenient yet eloquent brand name. An increasing number of companies worldwide have adopted the strategy of using foreign brand names in their various markets. (Melnyk, Klein, \& Völckner, 2012). Foreign branding defined as, the strategy of spelling or pronouncing a brand name in a foreign language which is targeted primarily toward influencing the brand image dimension of brand equity (LeClerc, Schmitt \& Dube, 1994).

The idea of foreign brand names is to utilize an appropriate, usually category-favorable, country image to influence consumers' evaluations of a product (Melnyk, Klein, \& Völckner, 2012). Prior empirical studies have shown that pronunciation in terms of phonetic structure (Yorkston \& Menon, 2004), the 'hardness' of consonants (Heath, Chatterjee, \& France, 1990), and different vowel sounds (Lowrey \& Shrum, 2007) effect consumer impressions of a brand name. In their study, LeClerc et al. (1994) stated that French pronunciation of a brand name effects hedonic perceptions of products. In contrast German pronunciation of a brand name effects utilitarian perceptions of products (Heslop \& Papadopoulos, 1993). Thakor \& Pacheco (1997) used Italian, French, and English brand names and found that French, Italian, and English brand names were perceived as equally hedonic, thus foreign brand named products were not perceived as more hedonic than domestic brand named products. Along similar lines, Soto et al. (2009) used English, French and Spanish brand names and found that French and English brand names associated more hedonic associations and English foreign brand names were liked more than French or Spanish brand names across hedonic, hybrid and utilitarian product categories.

Balabanis \& Diamantopoulos (2008) assess the validity of brand-origin assumptions and examine the extent to which consumers (precisely or imprecisely) attach or fail to attach a COO to a brand. Samiee et al. (2005) indicate that consumers recognize brands on the basis of brand-name associations with languages that refer to the brand origin. Harris, Garner-Earl, Sprick, \& Carroll (1994) examine consumer preferences for brand names in different languages when evaluating advertisements.

It is quite common to come across foreign brand names in most of all Turkish industries and markets, especially in textile industry (Rodi Jeans, Collezione, Jimmy Key, LC Waikiki, Journey), furniture industry (Lazzoni, Zebrano, Enza, Bellona), shopping malls (Arcadium, Astoria, Metrocity, Taurus, Ankamall), hospitals (Medicana, Memorial, Florence Nightingale), broadcasting networks (Show TV, Star TV, Flash TV, Capitol Radio, Joy FM ) as well as restaurants (Big Chef's, Butcha, Quick China, Paper Moon). In addition to these industries, it is also possible to see foreign brand names for other businesses such as pharmacies, hairdressers, bookstores along with toy stores and retail boutiques. The most preferred foreign brand names are observed to be English and Italian.

One of the main reasons why consumers prefer foreign named brands in Turkey is that, they perceive those brands with a higher level of confidence. The second reason is the high proportion of the young population in Turkey. Half of Turkey's population of seventy-five million is under the age of twenty-five. This argument is mainly based on the perception that young people, compared with other age groups, place greater emphasis on brands with the effect of popular (global) culture. Young consumers are also more prone to the influence of social factors such as peer group and aspirational group effects. This may lead them to be more responsive towards products with foreign brand names.

A research conducted on Turkish consumers' internet purchasing behaviors showed that foreign branding products have a significant impact on price (expensive) and quality (high quality) perceptions compared to local brands. The research also examined that foreign branding have a positive effect on brand image, brand trust and consumers' purchasing behavior (Baş \& Şahin, 2013).

Doğan (1999), in his research examined that choosing a foreign brand name for a local store did not have any central cause. On the other hand, he mentioned that personal trends and experiences come ahead than the other 
factors. He also stated that foreign branding is a natural outcome of an economic and cultural development for a country.

A product's association with a foreign origin may not always be positive due to the ethnocentrism of local consumers (Chan, Cui, \& Zhou, 2009). Shimp \& Sharma (1987) found that higher ethnocentrism among consumers were predictably related to both a preference for domestic goods and an aversion toward imports. In some of the municipalities in Turkey, local government officials authorized to increase taxes on companies who use foreign language on their products.

\section{Purpose of the Study}

There is a plethora of products with foreign brand names in the Turkish marketplace. This exploratory research study was designed to gain an understanding of Turkish consumers' attitudes towards products with foreign brand names and also to assess the impact of foreign brand names on their purchasing decisions.

Thus, the focal point of the study centers on the following research questions:

- Do foreign brand names have a different influence on consumer attitudes than national brand names?

- Do Turkish consumers tend to purchase products with foreign brand names more so than products with national brand names?

\section{Methodology}

The literature review conducted on recent articles in this particular stream of research revealed a common use of quantitative techniques for analysis. However, we decided to employ qualitative research and conduct in-depth interviews for this specific piece of research. We aimed to use an open-ended, discovery-oriented method, which would allow us to deeply explore the participants' feelings and perspectives about the issue of foreign branding and why it is such an epidemic in the Turkish market. Even though in-depth interviews are perceived as time-consuming and labor-intensive, the rich data that will be collected by these interviews will help to probe for deeper meaning and understanding about this complex issue.

Potential participants for the study were selected from an interview pool in the city of Ankara. Socio-demographic data were collected via a brief pre-interview questionnaire. Participants were between the ages of 18-69 years and represented different income and education groups. Between July 2013 and October 2013, twenty- three participants were interviewed at their homes or businesses. There were a total of ten questions, three of which were used as warm-up questions related with the topic. Each interview lasted between 45 and 90 minutes and focused on the consumer's experiences of products with foreign brand names, how they feel about them and their tendency to purchase. In the interviews, two groups of questions were attempted to be addressed.

Contextual questions had to with identifying the form and nature of what exists and diagnostic questions had to do with reasons for or causes of what exists. Interviews were audiotaped, transcribed, and analyzed according to the methods of framework analysis (Bryman \& Burgess, 1994). Developed by a specialist qualitative research unit called Social and Community Planning Research, framework analysis involves a systematic process of "sifting, charting and sorting material according to key issues and themes" (Bryman \& Burgess,1994). Transcripts were read repeatedly to identify the key themes and categories.

\section{Findings and Discussion}

As reflected on Table 1, participants were asked about their shopping frequency, sixteen of the twenty-three participants reported to go shopping at least once or more than once a week. Only one consumer stated to go shopping once every two weeks while six of them revealed that they shop once a month.

Table 1. Shopping frequencies of the respondents

\begin{tabular}{ll}
\hline Shopping Trips & Frequency \\
\hline Once a Week & 4 \\
More than Once a Week & 12 \\
Once Every Two Weeks & 1 \\
Once a Month & 6 \\
\hline
\end{tabular}

Out of the twenty-three participants, fourteen were between the ages of 19-30 and the remaining nine people were over the age of thirty-one. There were an equal number of female and male participants. Sixteen of the 
participants had an undergraduate and/or graduate degree and the rest of them were high school graduates. Twenty participants reported to speak English whereas five participants spoke German and only three knew how to speak French.

Table 2. Demographic profile of the sample

\begin{tabular}{lll}
\hline Factors & Criterion & Frequency \\
\hline Age & $19-30$ & 14 \\
& 31 and over & 9 \\
Gender & Female & 11 \\
& Male & 12 \\
Education & High School & 7 \\
& University & 13 \\
Monthly Income Level & Master/PhD & 3 \\
& $0-2000 \mathrm{TL}$ & 9 \\
Foreign Language & $2001-4000 \mathrm{TL}$ & 4 \\
& 4001 and over & 10 \\
& English & 20 \\
\hline
\end{tabular}

Participants were also enquired about where they like to go shopping. Twenty consumers reported their preference to shop at the malls, and nine favored retail stores \& boutiques. Eleven participants listed supermarkets but five chose local farmer markets as their top destination to shop. The results are depicted below in Table 3.

Table 3. Respondent's shopping place preferences

\begin{tabular}{ll}
\hline Shopping Places & Frequency \\
\hline Malls & 20 \\
Local Markets & 5 \\
Stores & 9 \\
Supermarkets & 11 \\
\hline
\end{tabular}

As reflected in Table 4, the participants were then asked whether they preferred to purchase branded products (foreign and/or national) in general. More than half of the sample group consumers claimed they always buy branded products.

Table 4. Respondent's branded product preferences

\begin{tabular}{ll}
\hline Branded Product Preference & Frequency \\
\hline Yes & 14 \\
No & 5 \\
Undecided & 4 \\
\hline
\end{tabular}

\section{Question 1: For what kind of products and/or product categories do you prefer foreign brand names?}

When the participants were asked to discuss what kind of products mattered the most in terms of having a foreign brand name, three product categories came into prominence. These categories were technological products, apparel $\&$ accessories and household appliances respectively. In addition, cosmetics, automotive as well as alcoholic beverages were noted to be significant product categories for foreign brand names. An interesting point to note here is that none of the consumers in the sample declared a choice for a foreign brand name product in the furniture category. However, there are many furniture retailers (Zebrano, Lazzoni, American Home) with foreign brand names operating in the Turkish market. 
"When I go shopping for personal care products like shampoo, deodorant or soap, I prefer to purchase products with foreign brand names. The reason is quite simple. I just believe that these brands care more for human health and they are not solely focused on economic gains." (Interview 3 : 60 year old woman with an undergraduate degree)

\section{Question 2: Do you prefer products with foreign brand names regardless of the product category?}

A majority of the respondents did not agree with this statement and declared that the category of the product was a driving force behind their need/ demand for a foreign brand name.

"I do not always care whether a product has a foreign brand name. To be honest, what really matters to me is what kind of product I am looking for. I tend to think that products with foreign brand names are higher in quality and earn consumers' trust. This is much more important if I am buying an expensive product like a television or a car. That is why the product class or category affects my decision to choose a product with foreign brand name." (Interview 5 : 23 year old man with a high school degree)

"I am mostly in favor of products with a foreign brand name. Especially if the product is worth a lot to me in terms of money or emotional value so I can say I do care about the product category" (Interview $8: 28$ year old woman with an undergraduate degree)

Question 3: Is there a differentiation in your purchasing decision when you try to choose a product with a foreign or national brand name?

All of the participants agreed with this question in their interviews and stated that they do indeed differentiate in their purchasing decisions. They mentioned that personal perceptions of quality, durability and safety factors cause this differentiation.

"I always opt for products with foreign brand name if the product has any impact on my health. I feel safer and more pampered by such products. I guess I perceive the foreign branded product's country of origin safer than my own country, in terms of production standards." (Interview 2: 38 year old woman with a graduate degree)

Question 4: Do you perceive a product with a foreign brand name to be superior when compared with a product with a national brand name?

Majority of the consumers in the study confessed that they felt products with foreign brand names to be much more superior. They reported that the notion of quality was the core of this superiority. However, several of the respondents did not agree with this and pointed out that superiority could be dependent not on the product, but the product category.

"Definitely yes. Quality, service, prestige. Products with a foreign brand name have all of these elements. I do not trust products with a national brand name. They are usually cheap, low-cost replicas of the original. Ifeel more hip and fashionable when I buy products with a foreign brand name. On another note, I believe our country's research \& development and engineering capabilities are below European countries." (Interview 1: 28 year old man with an undergraduate degree)

Question 5: If the product with a foreign brand name costs the same as the product with a national brand name, would you still prefer/choose the foreign brand named product? Why?

During the interviews, subjects pointed out that they would still prefer to buy the product with a foreign brand name even though it costs the same. Quality and reliability factors were specified as the main reason behind this decision.

"I will still go ahead and choose the product with a foreign brand name because I know that it will be more functional and it will have higher quality. I do not really care about price element at this point. " (Interview 7: 20 year old woman with a high school degree)

Question 6: Do you know the country-of-origin for the products you choose with a foreign brand name?

All twenty-three participants in the study stated their agreement with this question. They all revealed that they either know or learn the country-of-origin information for their choice product with a foreign brand name.

"I almost always know the country-of-origin of the foreign brand named product I purchase. I do my own research before I pick a particular product. Sometimes the product also stands out like Apple or Nike. Everyone knows where they come from. But I look up and learn if it is not so obvious." (Interview 14: 44 year old man with a graduate degree) 


\section{Question 7: Do you feel that it is important for products with foreign brand names to have eloquent and comprehensible brand names and other brand visuals (logo, mascot, etc.)?}

The participants were divided into two groups with regards to this question. The first group of consumers remarked that having eloquent and meaningful brand names and logos were crucial for a product's success. They added that such intelligent and comprehensible elements were pivotal in their purchasing decisions. However, the second group of consumers objected this view. These respondents stated they could care less about the visual elements and brand name itself. They stressed that the money was paid for the product itself, not these external elements. Their primary focus was on the functional and hedonic utilities provided by the physical product.

"The more eloquent and intelligent a brand name is, the more sophisticated the product's perception will be." (Interview 16: 31 year old woman with an undergraduate degree)

"I agree wholeheartedly. A pointed brand name, a well-marked slogan. Initially, these elements may get me interested in a product. If I get satisfied after my first purchase, I may get hooked on that product." (Interview 1: 28 year old man with an undergraduate degree)

"I am afraid I do not agree with this statement. To me, brand name and other brand elements are not prominent factors in my purchasing decision. I tend to pay attention to the product itself not its logo or mascot or slogan" (Interview 19: 63 year old woman with a high school degree)

\section{Conclusion}

There is a major prevalence of products and services with foreign brand names in many industries in Turkey. For this reason, the current research set out to assess Turkish consumers attitudes toward products with foreign brand names and the impact of these brand names on the purchasing decisions. There were two focal questions regarding this research. The first question evaluated whether products with foreign brand names had a different influence on consumer attitudes when compared with products with national brand names. The results of the in-depth interviews indicated that consumers have very positive attitudes toward products and services with foreign brand names. A majority of the participants revealed their perceptions of quality, reliability and prestige is strongly influenced by the product's foreign brand name. This finding supports Kaynak \& Cavusgil's (1983) earlier work which stated that consumers may swing away from inferior-quality domestic products when superior foreign products are available in the markets. However, participants in this study also mentioned that their attitudes toward foreign-made products changed remarkably across product categories. This shift in consumer attitudes can be explained by the structure of the competitive environment in the Turkish market.

Turkey is in a dynamic phase of its economic development during which the foreign brands are no longer perceived as ultimately superior to local brands by the Turkish consumers. In certain product categories, the local competition has started to exert a negative influence on the perception of foreign brands. In the last decade, several Turkish brands have achieved significant progress and became competitiors for some of the foreign brands in the market. For this reason, foreign brands must now face not only this rapid increase in the quality of domestic products but also the shift in Turkish consumers' perception levels.

The second major research question of the study focused on Turkish consumers potential tendencies to purchase products with foreign brand names more so than products with domestic brand names. Results from participant interviews supported this research question as well. Majority of the consumers in the sample confirmed their decision to purchase products with foreign brand names for a variety of reasons. At this point, it is crucial for foreign companies to explore the symbolism of consumption that is planted in the minds of Turkish consumers. Like their global counterparts, Turkish consumers tend to regard the brand as part of their social lives and their relationship to others in the society. They are looking for brands capable of providing both functional and hedonic utilities. However, it can be observed that Turkish consumers place a bigger emphasis on symbolic functions. This is apparent in the many ways products and services are consumed. In a society with a collectivist nature and high levels of social interaction, Turkish consumers dedication to symbolic value is not a surprise.

Brand name and other visual elements are part of the symbolic value that is perceived by the consumers. Some consumer research argues that the brand names and other visual elements are critical factors that affect purchasing decisions as they are perceived as a "high-scope" cue that has different meanings for a wide variety of attributes. Half of the participants in this study reported along similar lines, expressing that eloquent and comprehensible brand name and visuals were pivotal in their choices. As a result, branding can be viewed as a sufficient criterion for consumers' evaluation of a product, even to the point that it helps consumers stay away from other products or brands (Na, Holland, Shackleton, Hwang, \& Melewar, 2008). 
To sum it all up, the findings of this study will offer marketing managers and academics a better understanding of how consumers are likely to perceive foreign brands in comparison with national brands. In other words, these findings may have significant implications for domestic and foreign manufacturers with regards to the consumer-side effects of their decisions on branding strategies.

\section{Limitations}

The study provides insights to the consumer research with respect to the effects of foreign brand names on consumer attitudes and purchasing decisions. As with any study, this study has several limitations that highlight avenues for future research.

First, the data was collected from a small population in Ankara, representing a small part of Turkish consumer base; therefore, the findings of the study are limited in terms of generalizability. To generalize the results of this study, it would be desirable to carry out further research with a variety of participant groups across different parts of Turkey. The impact of demographic variables such as age, gender, level of education and standard of living may be assessed for both rural and urban consumers. The evolution of consumer perception for foreign and domestic brands is changing at a rapid face in Turkey, thus it would also be interesting to conduct research that focus on different generations of young and old Turkish consumers.

Second, the effects of foreign brand names on consumer attitudes can be differentiated by other factors such as the consumers' needs, their knowledge of the products, and product involvement level. Therefore, investigating the role of these factors can be considered possible directions for further research.

\section{References}

Aaker, D. A. (1991). Managing Brand Equity. New York: The Free Press.

Aaker, D. A. (1996). Building Strong Brands. New York: The Free Press.

Aaker, D. A., \& Joachimsthaler, E. (2000). Brand Leadership. New York: The Free Press.

Ailawadi, K., \& Keller, K. L. (2004). Understanding retail branding: Conceptual insights and research priorities. Journal of Retailing, 80(4), 331-342. http://dx.doi.org/ 10.1016/j.jretai.2004.10.008

Balabanis, G., \& Diamantopoulos, A. (2008). Brand origin identification by consumers: A classification perspective. Journal of International Marketing, 16(1), 39-71. http://dx.doi.org/10.1509/jimk.16.1.39

Baş, M., \& Şahin, Ş. (2013). Yabancı marka isimlerinin internet tüketicisinin satın alma davranışları üzerine etkisi: Teknolojik ürünler üzerine bir araştırma. Journal of Internet Applications \& Management, 4(2), 21-47. http://dx.doi.org/10.5505/iuyd.2013.57441

Bryman, A., \& Burgess, R. (1994). Analyzing Qualitative Data. London: Routledge.

Chan, T. S., Cui, G., \& Zhou, N. (2009). Competition between foreign vs. domestic brands: A study of consumer purchases in china. Journal of Global Marketing, 22(3), 181-197. http://dx.doi.org/10.1080/08911760902845015

Doğan, İ. (1999). Sokaktaki Yabancı İsyeri İsimlerine Yansıyan Kültürel Eğilimler. İstanbul: Sistem Yayıncılık.

Farquhar, P. H. (1989). Managing brand equity. Marketing Research, (September), 24-33.

Friedman, M. (1985). The changing language of a consumer society: Brand name usage in popular American novels in the postwar era. Journal of Consumer Research, 11, 927-938.

Harris, R. J., Garner-Earl, B., Sprick, S. J., \& Carroll, C. (1994). Effects of foreign product names and country-of-origin attributions on product evaluations. Psychology \& Marketing, 11(2), 129-144. http://dx.doi.org/10.1002/mar.4220110204

Heath, T. B., Chatterjee, S., \& France, K. R. (1990). Using the phonemes of brand names to symbolize brand attributes. Proceedings of the American Marketing Association, 3, 8-42.

Heslop, L. A., \& Papadopoulos, N. (1993). Product-Country images-Impact and Role in International Marketing. New York: Haworth Press.

Kaynak, E., \& Cavusgil, T. (1983). Consumer attitudes towards products of foreign origin: Do they vary across product classes? International Journal of Advertising, 2, 147-157.

Keller, K. L. (1993). Conceptualizing, measuring and managing customer based brand equity. Journal of Marketing, 57(1), 1-22.

Keller, K. L. (1998). Strategic Brand Management: Building, Measuring and Managing Brand Equity. Upper 
Saddle River: Prentice Hall.

Kohli, C., Harich, K., \& Leuthesser, L. (2005). Creating brand identity: A study of evaluation of new brand names. Journal of Business Research, 58(11), 1506-1515. http://dx.doi.org/10.1016/j.jbusres.2004.07.007

Kotler, P. (1994). Principles of Marketing. New Jersey: Prentice Hall.

Kwang, J. N., Holland R., Shackleton, J., Hwang Y. Y., Melewar, T. C. (2008). The effect of evaluation criteria on design attributes and brand equity in the product evaluation process. Journal of Brand Management, 16(3), 195-212. http://dx.doi.org/10.1057/bm.2008.29

LeClerc, F., Schmitt, B. H., \& Dubé-Rioux, L. (1989). Brand name a la française? Oui, but for the right product. Advances In Consumer Research, 16, 253-257.

LeClerc, F., Schmitt, B., \& Dub'e-Rioux, L. (1994). Foreign branding and its effects on product perceptions and attitudes. Journal of Marketing Research, 31(2), 263-269.

Lowrey, T. M., \& Shrum, L. (2007). Phonetic symbolism and brand preference. Journal of Consumer Research, 34(October), 406-413. http://dx.doi.org/10.1108/07363761111181509

Melnyk, V., Klein K., \& Völckner, F. (2012). The double-edged sword of foreign brand names for companies from emerging countries. Journal of Marketing, 76(6), 21-37. http://dx.doi.org/10.1509/jm.11.0349

Park, C. W., Jaworski, B. J., \& Maclnnis, D. J. (1986). Strategic brand concept-image management. Journal of Marketing, 50(October), 135-45.

Raggio, R., \& Leone P. R. (2007). The theoretical separation of brand equity and brand value: managerial implications for strategic planning. Journal of Brand Management, 14, 380-395. http://dx.doi.org/10.1057/palgrave.bm.2550078

Ritchie, J., \& Spencer L. (1993). Qualitative data analysis for applied policy research. In A. Bryman \& R. Burgess (Eds.), Analyzing Qualitative Data (pp. 173-194). London: Routledge.

Samiee, S., Shimp, T. A., \& Sharma, S. (2005). Brand origin recognition accuracy: its antecedents and consumers' cognitive limitations. Journal of International Business Studies, 36(4), 379-397. http://dx.doi.org/10.1057/palgrave.jibs.8400145

Shimp, T. A., \& Sharma, S. (1987). Consumer ethnocentrism: Construction and validation of the CETSCALE. Journal of Marketing Research, 24(8), 280-289.

Silverman, D. (1993). Interpreting Qualitative Data. London: Sage Publications.

Soto, S. O., Mobarec, E. M., \& Friedmann, R. (2009). Foreign branding: Examining the relationship between language and international brand evaluation. Innovar, 19(35), 9-18.

Thakor, M. V., \& Pacheco, B. (1997). Foreign branding and its effects on product perceptions and attitudes: A replication and extension in a multicultural setting. Journal of Marketing Theory and Practice, 5(1), 15-29.

Yorkston, E., \& Menon, G. (2004). A sound idea: Phonetic effects of brand names on consumer judgements. Journal of Consumer Research, 31, 43-45. http://dx.doi.org/10.1086/383422

\section{Copyrights}

Copyright for this article is retained by the author(s), with first publication rights granted to the journal.

This is an open-access article distributed under the terms and conditions of the Creative Commons Attribution license (http://creativecommons.org/licenses/by/3.0/). 